\title{
LOST, FAN CULTURE AND THE NEO-BAROQUE
}

\author{
Angela Ndalianis \\ Faculty of Arts \\ Room 217, John Medley Building \\ Screen and Cultural Studies \\ School of Culture and Communication \\ University of Melbourne \\ Melbourne, Victoria, Australia \\ angelan@unimelb.edu.au
}

[Anuario calderoniano (ISSN: 1888-8046), 5, 2012, pp. 35-50]

\section{The Play of Cult}

Emerging in the mid $20^{\text {th }}$ century when Disneyland opened its doors in 1955, the theme park created the ultimate in trompe l'oeil effects that collapsed the screen frame by extending the fictional world of Disney animation into the social sphere. In researching the design of Disneyland and how its spaces would reach out to its navigators, Walt Disney learned many lessons from the urban design practices of earlier European traditions, including Andre Le Nôtre's axial designs for Louis XIV's Versailles residence and gardens. But whereas the vast landscapes and buildings of Versailles stood as monuments to the 
grandeur of their $17^{\text {th }}$ century aristocratic patron, King Louis XIV the Sun King, in the $20^{\text {th }}$ century Disneyland stood as a monument to the nascent Disney Corporation and the masses who navigated its worlds. Disneyland and the theme parks that followed, take as their starting point a fictional media premise (from a film, television show, comic book etc) and aim to produce a networked environment that conjures wondrous spaces that both perform for the audience and which are for performing within. In this essay, however, I'll be looking not at the theme park, but at the medium of television. In doing so, I will explore how, in recent years, television shows have strategized alternative ways of producing performative spaces for their audiences — spaces that are as baroque in nature as examples of their historical predecessors. Through close analysis of the television show Lost $^{1}$ I will look at the ways in which this series draws upon the baroque concept of bel composto or, the unity of the arts. As is typical of other entertainment media examples including the television show

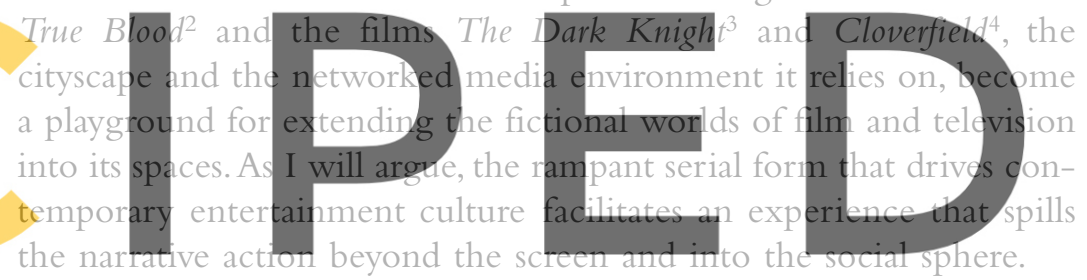

The historical Baroque is a period renown for the production of

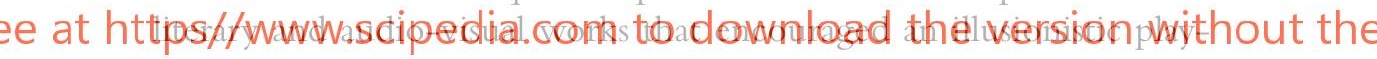

fulness and narrative labyrinthicity that evoked levels of reality. From the writings of Miguel de Cervantes, Caldéron de la Barca and William Shakespeare, to the paintings of Diego Velázquez, Pietro da Cortona and Giovanni Battista Gaulli, the boundaries that distinguished reality from fiction bled into each other and, in the process, generated multiple narrative possibilities and parallel realities the defied the audience to untangle and locate a containable representational world. Integral to the success of these narrative worlds was the key role played by the spectator as active participant in the performance - an activ-

\footnotetext{
${ }^{1}$ ABC, 2004-2010.

$2 \mathrm{HBO}, 2008$.

${ }^{3}$ Nolan, 2008.

${ }^{4}$ Reeves, 2008.
} 
ity that ranged from recognizing and cognitively engaging with iconographic and allegorical programs to, in the case of theatrical events, actually participating as actor in the performance itself. Performativity and acknowledgement of the audience was an integral feature of the art and theatre of the historical baroque. In Gods of Play: Baroque Festive Performances as Rhetorical Discourse, Kristian Aercke argues that the display of theatrical productions were integral to «Baroque absolute rulers who sponsored such celebrations»; often participating as actors the production, the performances were considered to be a «very serious form of play» that placed the ruler at the centre of the universe, and which functioned as a «play of cult»" Drawing on the writings of Georges Bataille, Aerke states that the play of cult was reliant on the production of the theatrical performance, which became a «sacred thing» that symbolized the «status of the sponsor-ruler»; surpassing «the fleeting entertainment value of the performance», the play of cult represented in microcosmic form the real-world power of the ruler ${ }^{6}$. One of the most dramatic examples of this display was the carousel held
in Versailles in 1662 where, dressed as Roman Emperor, King Louis
XIV performed the role of the Sun King. Placed at a metaphorical
center of the universe, ueach of the participating noblemen informed
the sponsor-rule-imperator of his specific attachment by means of al-
legorical representations and devices, many of which implicd or sim-

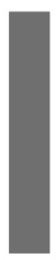

ulated the need for the sun»?

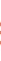

and modes of engagement that were more familiar to the aristocracy of the $17^{\text {th }}$ century historical baroque, and an obsessive sense of the "play of cult» is evident in the ways in which participants engage with and consume media texts. The "sacred thing" that was the ruler as object of worship has, however, now migrated to the television show, the film, the computer game etc and to the producers and directors responsible for their creation. It is crucial, however, to understand that the neo-baroque has developed within a radically different social context, one that is nurtured by the era of globalization, media conglomeration and digital technologies. As such, while there are shared

\footnotetext{
${ }^{5}$ Aerke, 1997, p. 4.

${ }^{6}$ Aerke 1997, p. 5.

${ }^{7}$ Aerke 1997, p. 25.
} 
formal, thematic and spectator positions between the two periods, the articulation and ultimate intention of the expression of the neobaroque is also dramatically different to that found in the earlier baroque period, which was roughly associated with the $17^{\text {th }}$ and $18^{\text {th }}$ centuries. As I have argued elsewhere ${ }^{8}$, contemporary culture at large - from entertainment media, to museums, to retail complexes, to new urban redevelopments - has given new expression to the baroque and this is expressed in diverse ways. For the purpose of this essay, however, my main example focuses on the new storytelling practices and audience reception found in the television series and, more specifically, cult television series. As will be argued, the result is that the "play of cult» that finds expression in $21^{\text {th }}$ century television shows like Lost invite the audience to celebrate and become part of a sacred media world that has, at its core, a radically different ideological purpose compared, for example, to the abovementioned performance of Louis XIV as Sun King. To extend the metaphor, the role of the new Sun
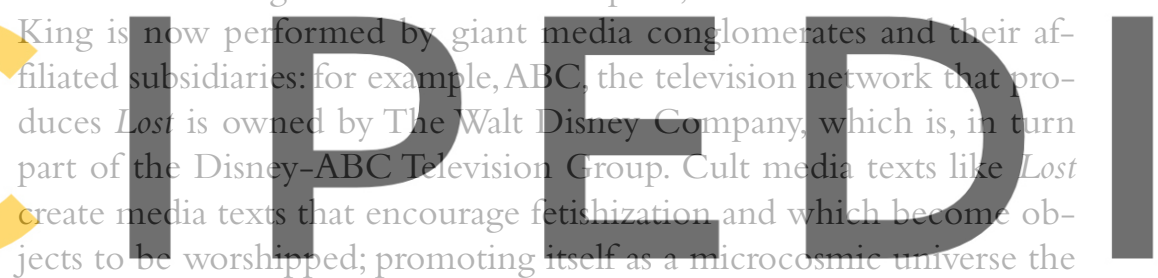

series invites intense forms of audience participation. In the process,

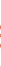
er on the company $(\mathrm{ABC})$ and media conglomerate (Disney- $\mathrm{ABC}$ ) that brought it into existence in the first place.

\section{Lost, Fans and Overconsumption - a «Minor Baroque»?}

Reeves, Rodgers and Epstein discuss the relationship between what they describe as «TV I's casual viewing and cult TV's avid fanship». TV I, which was a form of viewing very much aligned with network era television and Fordism, was superseded during the more recent era of conglomeration, diversification and digitization with TV II.They explain:

${ }^{8}$ Ndalianis, 2004. 
TV II exhibits a complicated product/producer relationship with postFordism. In other words, TV II's combination satellite and cable distribution system, augmented by remote controls, personal computers, and video cassette recorders, in conforming to the grand logic of flexible accumulation has also played a decisive role in naturalizing that logic and promoting the values of its overconsumptionism ${ }^{9}$.

While cult films and television shows released prior to the 1980s were embraced by fan culture, it is in the decades since that fan communities have boomed and cult has entered the mainstream driven by what Reeves, Rodgers and Epstein correctly label as the impulse of "overconsumptionism» ${ }^{10}$. The era of TV II may, in fact, already have transitioned into TV III: new dissemination and viewing technologies such as DVDs, ipods, PSPs, internet on television, and specialist cable and satellite stations such as Syfy and $\mathrm{HBO}$ that cater specifically to fan tastes all facilitate an ease of access to fan objects that's never been witnessed before Add to this online chat-rooms, blogs, fan sites and, more recently, studio-hosted fan sites and we see encre what Kenry Jenkins calls the collective intelligence of participatory culture. As Jenkins explains, conglomeration and digital technologies have resulted in a convergence culture that connects and makes between producers and consumers around media sult is a complex set of viewing environments and modes of interacee at https, that nurture the cult experienge, fan fulture and the worship of

For example, in addition to all the fan-run online activity, ABC the show's production company - has a website that targets fans of Lost $^{12}$. In addition to being able to download episodes or watch them online, fans can access: bonus scenes and behind-the-scenes clips; news updates; links to Lost on Twitter and Facebook; an online store; a Lost magazine; forums that focus on the series where fans can read, hear and see interviews with the show's actors, writers and producers; and wallpapers, photos, podcasts and interviews with the series' creative talent. Beyond these more general features and services that are now

\footnotetext{
${ }^{9}$ Reeves, Rodgers and Epstein, 1996, p.29.

10 See also Gray, 2007 and Gwenllian-Jones and Pearson, 2004.

11 Jenkins 2006, pp. 25-58.

$12 \mathrm{http} / / /$ abc.go.com/shows/lost.
} 
run of the mill for television series, the cult nature of Lost also requires a more idiosyncratic approach that is more familiar to cult experiences. On the "Commentary» site, for example, fans can access episodes that have commentaries laid over them by show writers, directors and other creative crew, and while this may just extend the DVD «extras» feature, the functionality of this site goes further in that it allows fans to add their own commentary track to any ABC episode available online in the ABC.com Player and share it with others through a Facebook feed. «Mysteries of the Universe» provides footage and documentaries about the Dharma Initiative, the organization behind many of the conspiracy-related stories that wove their way through the television series. And the "Lost Encyclopedia» is a muchneeded resource that provides information about the mind-boggingly complex mythology, characters and events that comprise the series and which the Lost fan is required to immerse themselves in if they are to actively participate in events that are associated with the Lost
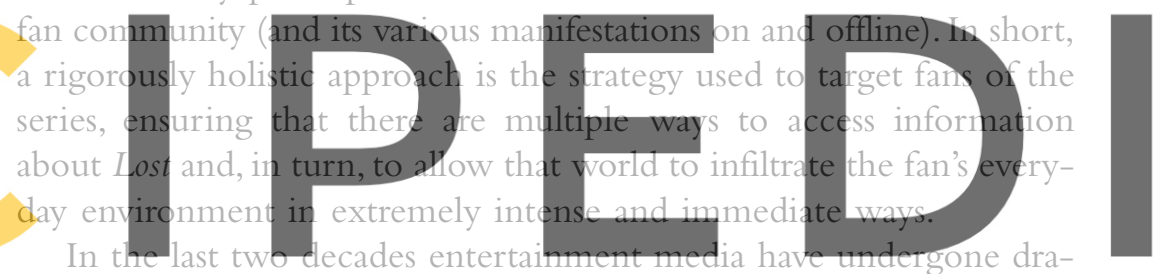

matic transformations that also amplify the performative potential of

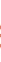
these changes is one concerned with the traversal of boundaries. Shows like Lost, for example, have played a significant, even groundbreaking, role in creating storytelling strategies that extend the fictional spaces of their TV universes into the media worlds of mobile phones, podcasts, comic books, novels and the Internet. But beyond this, embracing the era of viral marketing and a new form of storytelling that relies heavily on social networking sites like YouTube, Facebook, and Twitter, they have also encouraged the transformation of the cityscape itself into a theatrical space that's about performance. The television show Lost, and The "Lost» Experience alternative reality game that developed from it drives home the fact that meaning and coherence of the text in media culture of the last decade is reliant upon an audience that's capable of embracing multiple-media «texts» in order to extract more complex layers of meaning from the experience that is 
the television series. The "Lost» Experience ran alongside the second season of Lost. Labeled a "game» and influenced by one of the earliest forays into viral marketing as storytelling strategy - Steven Spielberg's "Beast" game that preceded the release of the film A.I. (2001) - it is that and so much more. By adapting the «rules» of viral marketing, which rely on targeting an audience stealthily through wo rd-of-mouth (primarily through a gimmick delive red on the Internet), the Lost team presented their content in the hope that 'players' would spread the uexperience» further and, even more so, bring their experience of «viral Lost» back with them to inform their understanding of 'TV-Lost'. From here, an elaborate web of clues, story information and possible conspiracies could be investigated by fans in the hope that they could solve many of the TV show's mysteries, including that of the elusive polar bear.

The «Experience» involved the audience becoming integrated into extended Lost stories; some unraveled on the web, some on television and some in the player's nreal» space. For example, Hanso Foundation
advertisenents were aired during the commercial breaks for the Lost
TV series, for example, and included a number to call that provided
information about the Hanso Foundation website. Here playes then
discovered that the Hanso Foundation, through its funding of the
Dharma Initiative the secret science project apparently funded by the

Hanso Foundation in the 1970s) was involved in the construction of

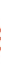

all information that viewers had at that stage about the Hanso Foundation was drawn from its fictional Web site, TheHansoFoundation.org and other sites that were part of The "Lost» Experience, rather than narrative events occurring in the television series. In addition, a fictional Oceanic Airlines website posted announcements about flight cancellations and players could check for the victims of flight 815; and the site ApolloCandy.com appeared and promoted a chocolate bar named Apollo (which characters had been seen eating in the TV series) - and it was later revealed that the Apollo Candy Company was bought by Alvar Hanso, the founder of the Hanso Foundation. Through a series of fictitious blogs (in Australia it was the Lost Ninja blog) were presented as being posted by «real» people — and here it was announced that some Apollo Candy bars had 'fallen off the back of a truck' and managed to make it to certain locations around the 
world, which meant that the avid fan/participant in the conspiracy could make their way to stores to claim their very own Apollo chocolate bar (after saying the secret password: "what did one polar bear say to the other polar? "). On the television show Lost, it was also disclosed that the character Gary Troup was an author who died in the crash of Oceanic Flight 815, but that before getting on the flight he had delivered a manuscript called Bad Twin to his publisher (characters in the show are seen reading the manuscript). The assumption in the fictional space was that the manuscript was published and, fans who followed the clues scattered across the series and visited Amazon.com could (and still can) purchase a copy of Bad Twin; during the time the Hanso Foundation published newspaper advertisements in «real» newspapers that condemned the novel. In «reality», $A B C$ teamed with Hyperion Books — another Disney subsidiary — to publish the manuscript Bad Twin, which was written by Laurence Shames with guidance from show's writers. Gary Troup (played by an actor)
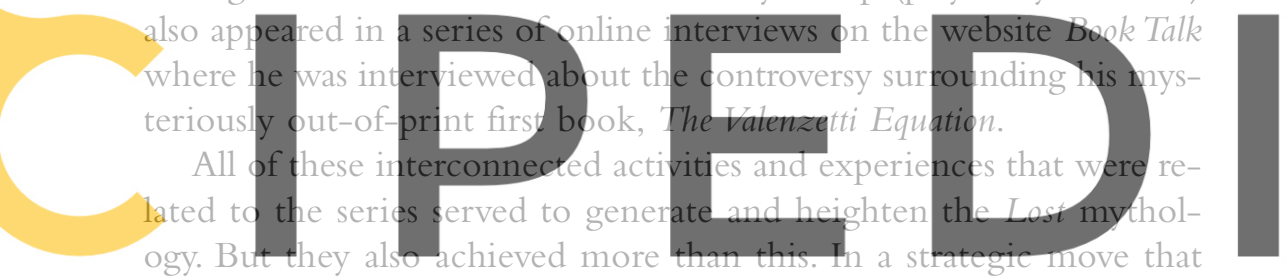

would do Bernini proud, the Lost creators were intent on blurring

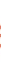

gies, in this respect, was the character Rachel Blake (also known as Persephone), who was introduced to guide players through The "Lost» Experience but to also encourage the real world conspiracy: the idea being that the secret experiments taking place on the island had actually taken place in our reality. As a supposedly 'real' person who had exposed Hanso, she wrote blogs and had her own website, and she uploaded interview exposes with Alvar Hanso - the man behind the Lost mystery - onto YouTube. And, at one famous event that took place at the San Diego Comic Con in 2006, in a room full of thousands of fans, Rachel Blake stood up and confronted the Lost writers, stars, and producers on the panel, demanding they tell the truth about the real-life conspiracy that they were covering up. As the panel insisted that the show was only fictional, and accompanied by the cheers 
and applause of fans in the crowd, Rachel Blake was carried off by Comic Con security ${ }^{13}$.

In his book, The Theater of Truth: the Ideology of (Neo)Baroque Aesthetics, William Egginton takes issue with my consideration of contemporary entertainment practices as expressions of a neo-baroque poetics. In a lengthy passage worth quoting, he states the following:

There is a blurring — favored by the military-entertainment complexes of new and old empires alike- that suggests to the participant that the borders distinguishing base reality from a given representation are fungible, only insofar as the base reality is taken as sacrosanct. I have elsewhere called this illusionism... the observation that the illusionism of Hollywood cinema and the spectacle of the fashion industry, no matter how worthy of admiration their techniques might be, both function ultimately as lures for the production of docile consumers; the bait of difference, of individuality, is proffered in the service of mass commodification. Art and literature that deploy the minor strategy of the Baroque cannot be copted by this commodification (a though they can certainly
be consumed as commodities, which is different), because the very func-
tion of the strategy undermines the basis for identification necestary for
mas commodification. The impu.se to locate ourselves as consume-s of
spectacle, in other words, relies on the bracketing of an agency ostensibly
untuched by that choice: the vidwer who can chodse to be fightened by Alien or don these designer jeans in order to fit a certain standard of

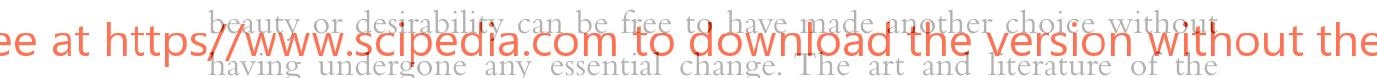

Coloneobaroque challenge that basic assumption by attacking the foundational distinction between the unquestioned base reality and its muitipie representations. Such art and literature goes beyond the mere excitement of affect to affect the core of our being, since it leaves us with the uncanny sense that this core is at play in the world of representations ${ }^{14}$.

Focusing on the illusion/reality interplay that's integral to the baroque, Egginton makes a crucial error, an error that's informed by a binary logic that perceives "high» art examples as presenting a truer, more correct articulation of the more lowly examples of mass culture and the media conglomerates that seek to profit from their products.

13 http://www.youtube.com/watch?v=QvVJNYZ5PuQ (accessed 1/8/10:10).
${ }^{14}$ Egginton, 2010, pp. 83-84. 
While acknowledging he can be accused of "snobbery» in "defense of higher, more literary and artistic production against popular culture» 15 he nevertheless proceeds to close himself off to a more comprehensive analysis of examples of mass culture; he applies the latter to works that move beyond what he calls a «minor» baroque expression (works that play on illusionism but which lack deeper meaning). I take issue with Egginton's misunderstanding of the complexities inherent to popular culture.

As is the case with the ideological imperative that drove aristocratic rulers to commission grand spectacles during the historical baroque, to be a consumer of popular culture does not necessarily imply blind allegiance to the ideologies associated with Late Capitalism. The «docile consumer» can indeed consume while simultaneously being conscious of the process of consumption he or she engages in, taking from it and transforming it into something personal and unique that extends beyond initial imperatives. It goes without saying that The

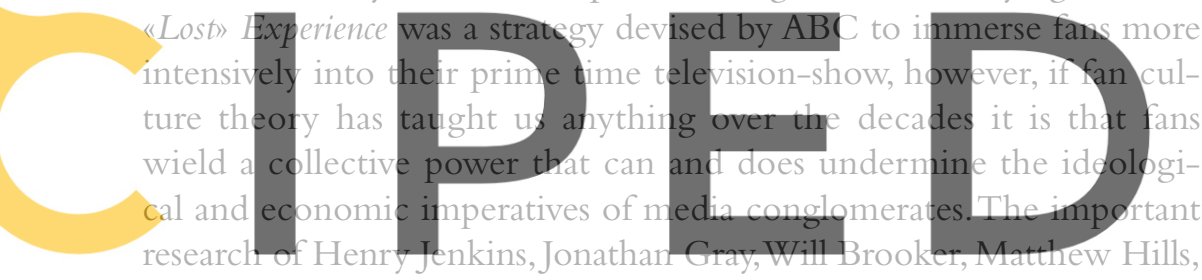

Sara Gwenllian-Jones and Roberta E. Pearson —amongst others - has

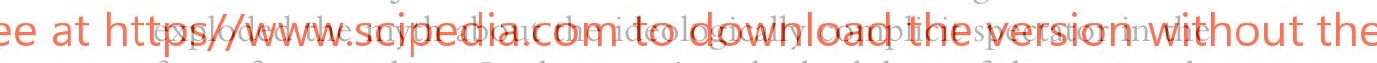

face of mass culture. In short, against the backdrop of the postmodern (post-postmodern?) age, we need to accept that new rules are in play, and that the critical discourse of an older school of critical thought (clouded by Marxist-Althusserian discourse) needs to be reconsidered. Yes, as Egginton explains, one of the strategies of the baroque is its more radical potential, but this radical practice is not to be found solely in the domain of high art. This tendency towards providing deeper readings of "high» examples is especially evident in Egginton's mode of analysis. For example, in the chapter that immediately follows the above quotation, he launches into an analysis of Calderón's La Vida es Sueño (Life is a Dream), which «is doubtlessly one of the masterpieces of the Spanish Golden Age theater and of

15 Egginton, 2010, pp. 84. 
western theater in general» ${ }^{16}$. Providing a reading that examines the text and Calderón's philosophical explorations regarding the nature of life and reality within the context of $17^{\text {th }}$ century thinking, he neglects to address something equally as crucial: the context in which this text was first presented. Calderón worked for the court of Philip IV of Spain and this fact also places La vida es sueño within a regressive ideological framework. However, one of the most powerful features of the baroque lies in its dialogical process, and the contexts that generate texts as varied as La vida es sueño and Lost give rise to a dialogic relationship that sees both regressive and progressive (enlightened?) elements struggle for attention and in this struggle, neither wins and both win.

Before concluding this discussion, let me return to the example of Lost and The "Lost" Experience. What we are presented with is a serialized web of extended stories that are available to the audience if they are willing to following the story threads. Relying on the baroque concept of "world within a world", The "Lost» Experience «is fiction in our world, and the television show Lost exists in the world created by The "Lost» Experience» ${ }^{17}$. In the words of Egginton, in its play on illusionism, we appear to have an expression of the "minor baroque» and yet, as I will explain below, there is nothing minor about it. Ultimately, The "Lost» Experience bargains on its placement within our reality for its status as «real». Invoking a neo-baroque articulation of a "unity of the arts", the Lost creative team created a $21^{\text {th }}$ century version of bel composto - the beautiful union of multiple media. Diverse media - television, you tube, web sites, DVDs, podcasts, real geographical locations - combine in a harmonious whole and, in the process «surpass their own limits, transcending one into another»" Careri argues that the effect of the bel composto on the baroque viewer is one that creates a "montage consisting of a series of progressions or leaps from one component of the composto to another» ${ }^{19}$, and while he discusses the work of Bernini, the same principle of bel composto holds for the encounter of the Lost fan. Compared to the his-

\footnotetext{
16 Egginton, 2010, pp. 85-86.

17 Casey, 2006, n.p.

18 Careri, 1995, p. 8.

19 Careri, 1995, p. 2.
} 
torical baroque a radically different audio-spectatorship is generated as a result of the centrality played by diverse electronic media, yet the perception and experience of Lost across each medium - whether the experience of an episode on television, a «real» exposé of the Dharma Initiative on You Tube, a podcast downloaded from itune onto a mobile phone, or the experience of Rachel Blake live at the Comic Con. Each component combines to give the participant both a more participatory experience of the series and a more comprehensive and complete understanding of the narrative events occurring in the complexity and seeming chaos that is the Lost universe. Exploring my argument about the neo-baroque and its polycentric nature ${ }^{20}$, Michelle Lang, argues that:

The philosophy of the Neo-Baroque is intertwined with postmodernism, where "truth» and "reality" have no absolute definition and rigid, static boundaries exist to be transgressed. In both the Baroque and NeoBaroque, time and space can be elements of form and content, emotion and perception can be both process and theme ${ }^{21}$.

At the centre of Lang's argument is the concept of the bel composto, which she explores through the concept of the "total work of art». The "Lost" Experience insists on a fiction that has a fluid relationship to a variety of media - from the television show, to DVD extras, to websites, to YouTube, to actual geographic locations - these all operate in unity to complicate the Lost mythology. Each fragment builds up like a puzzle to be experienced and be solved, all the while relying on the porous understanding of «reality" and «truth». With regard to the work of Bernini, Careri states that the bel composto «is an aesthetic operation in which the heterogeneous multiplicity of the ensemble is taken apart and recomposed by the viewer himself $\rangle^{22}$. Television shows like Lost present a neo-baroque articulation of the concept of "theatre of the world", and the process whereby the world and theatre, reality and fiction blur is facilitated by a formal approach that favors an open, polycentric structure. Here, the multiplicity that Careri speaks of is integral to the viewing experience and requires ac-

\footnotetext{
20 Ndalianis, 2004.

${ }^{21}$ Lang, 2006, n.p.

22 Careri, 1995, p. 5.
} 
tive engagement on the part of the audience in order that sense may be made of object of cult play. I've argued elsewhere regarding the neo-baroque seriality of contemporary television ${ }^{23}$, but Lost takes the seriality of television to new limits by spilling the medium boundary of television across multiple media and into the everyday environment. In the process, in the theatre that is "Lost», the viewer / participant becomes yet another component of the bel composto.

\section{Lost, Seriality and Leibnizian Worlds}

Science fiction and fantasy genres have, historically, been more susceptible to the wiles of cult. Yet, as Gwenllian-Jones and Pearson explain, cult films belong «to a "paracinematic culture" that seeks to promote an alternative vision of cinema", one that questions "the legitimacy of reigning aesthetic discourses» which favor linear, selfcontained stories that aspire to narrative resolution and closure ${ }^{24}$. That which distinguishes cult film from cult television is "a characteristic shared with the many other American television dramas»: the serial form.

Interconnected story lines, both realized and implied, extend far beyond any single episode to become a metatext that structures production, diegesis, and reception. Cult television's imaginary universes support an inexhaustible range of narrative possibilities, inviting, supporting, and rewarding close textual analysis, interpretation, and inventive reformulations ${ }^{25}$.

The conditions and secret ingredients that generate the cult experience can become dramatically amplified by the serial logic of television and, in the process, attract audiences that «inspire significant interpretive fan cultures» that frequently diverge from the meanings "intended" by the television show producers ${ }^{26}$. The very nature of these series is to be participatory and to become immersed in an emer-

\footnotetext{
23 Ndalianis, 2005.

${ }^{24}$ Ndalianis, 2005.

25 Gwenllian-Jones and Pearson, 2004, p. XII.

26 Gwenllian-Jones and Pearson, 2004, pp. X-XI.
} 
gent mythological universe that rewards an understanding of its content. Discussing computer games Celia Pearce has explained that the narratives of this medium are emergent in that they are always in the process of becoming. As such, the narratives are playing with the player as much as the player plays with them. This is precisely the sensation that The "Lost» Experience bargains on: the illusion that participants are contributing to an emergent narrative. Yet this is not mere illusionism for the sake of technical or technological bravura. By extending the story of the television series into the wider social realm the show's writers we re also extending a key thematic that runs through the entire series, one that is indeed Calderónian at its very core: the series from its beginning has questioned the nature of identity and reality by exploring the stability/instability of both through the opposing voices of science and religion. The show's moral core is found in the character John Locke who is the embodiment of the "essay in human understanding» that his namesake explored over three centuries ago: radiating around John Locke, the narrative and characters of Lost are a powerful exploration of questions regarding the consciousness, fate, perception and existence.

The final season of the Lost brings to dramatic crescendo the collision of science and faith but offers no concrete answers that provide a solution to the story's proliferation of alternate realities - past, present, future and concurrent. Season 4 of the series, for example, flashed forward to a future reality of the Oceanic Six survivors who had escaped the island, while the story also depicted the "present» events on the island. Season 5 continues with the «future» survivor timeline, finally having then return to the island, to be reunited with those who remained behind who spent the season jumping backward and forward in time until they finally stabilized in 1974. Further tampering with time ensues, then in Season 6 the flash-sideways narrative is introduced which offers an alternative existence to that being experienced by the same characters on the island. In the flash-sideways, Oceanic Flight 815 never crashed. All the 'realities' presented remain slippery and beyond the grasp of firm knowledge or understanding. Lost performs a role that's uncannily similar to that outlined by baroque philosopher and mathematician Gottfried Leibniz. Leibniz argued that multiple versions of possible realities existed and God selected the one that would come into existence. Paralleling (and in- 
fluencing what would later become) quantum theory and the hypothesis of the coexistence of many worlds ${ }^{27}$, in his Discourse on Metaphysics (1686) and later works, Leibniz expounded a theory of multiple possible worlds that progress as series. Leibniz's argument regarding the Identity of Indiscernibles posits a God who generates multiple possible worlds but, ultimately, reduces this multiplicity to a singular, actual world that finally comes into perfect existence ${ }^{28}$. One among so many questions that remain unanswered in Lost is who created these multiple realities — was it God or was it Science? Both are presented as possibilities yet neither is revealed to be victor in giving form to the allusive and mysterious thing that is life. Egginton argues that to be truly baroque it is necessary to go «beyond the mere excitement of affect to affect the core of our being, since it leaves us with the uncanny sense that this core is at play in the world of representations». Ultimately, Lost achieves this with intense mastery and the viewer who has chosen to embrace this fictional world is indeed affected to the very core of their being.

27 Everett, 1973.

28 See Saville, 2002, pp.121-44. 


\section{BIBLIOGRAPHY}

Aercke, K., Gods of Play: Baroque Festive Performances as Rhetorical Discourse, Albany, State University of New York Press, 1997.

Brooker, W., Using the Force: Creativity, Community and Star Wars Fans, London, Continuum, 2003.

Careri, G. Bernini: Flights of Love, the Art of Devotion, intr. H. Damish, Chicago, University of Chicago Press, 1995.

Casey, S., "Frame Story / Historical Fiction: Understanding The "Lost» Experience», Lost Online Studies, 1, 3, 2006. Available at: http://www.loststudies.com/1.3/frame_story.html.

Gray, J., Fandom: Identities and Communities in a Mediated World, New York, New York University Press, 2007.

Egginton, W., The Theater of Truth: the Ideology of (Neo)Baroque Aesthetics, Stanford, Stanford University Press, 2010.

Everett, H. III., «The Theory of the Universal Wavefunction», en The Many-

Worlds Interpretation of Quantum Mechanics, eds. B. DeWitt y R. Neill Graham, Princeton, Princeton University Press, 1973, pp. 3-140.

Gwenllian-Jones, S. y Pearson, R. E., "Introduction», en Cult Television, eds.

S. Gwenllian-Jones y R. Pearson, Minneapolis, University of Minnesota Press, 2004, pp. IX-XIX.

Hills, M., Fan Cultures, London / New York, Routledge, 2002.

Jenkins, H., Convergence Culture: Where Old and New Media Collide, New York, New York University Press, 2006.

- Textual Poachers: Television Fans and Participatory Culture, New York / London, Routledge, 1992.

- Fans, Bloggers, and Gamers: Media Consumers in a Digital Age, New York, New York University Press, 2006.

LANG, M. A., "Lost as Neo-Baroque», Lost Online Studies, 1, 3, 2006. Available at: http://www.loststudies.com/1.3/neobaroque.html.

Ndalianis, A., Neo-Baroque Aesthetics and Contemporary Entertainment, Massachusetts, The MIT Press, 2004.

- «Television and the Neo-Baroque», en The Contemporary Television Series, ed. L. Mazdon and M. Hammond, Edinburgh, University of Edinburgh, 2005, pp. 83-101.

Pearce, C., "Story as Play Space: Narrative in Games», en Game On: the History and Culture of Videogames, ed. L. King, London, Laurence King Publishing, 2002.

Reeves, J., Rodgers, M. y Epstein, M., «Rewriting Popularity: The Cult Files", in Deny All Knowledge: Reading the X-Files, ed. D. Lavery and A. Hague, London, Faber and Faber, 1996, pp. 22-35.

Saville, A., Leibniz and the Monadology, London / New York, Routledge, 2000. 